\title{
Adaptive Port Planning under Disruptive Trends with focus on the case of The Port of Kuala Tanjung, Indonesia
}

\author{
Andre Prakoso ${ }^{1, *}$, Poonam Taneja ${ }^{2}$, and Tiedo Velinga ${ }^{2}$ \\ ${ }^{1}$ Delft University of Technology, Master program in Hydraulic Engineering, Delft, The Netherlands ${ }^{2}$ Delft University of Technology, \\ Hydraulic Engineering Department, Delft, The Netherlands
}

\begin{abstract}
As a national strategic project, the Port of Kuala Tanjung draws significant attention at national and international level. Considering the semi-greenfield nature of the port, the diverse set of stakeholders, and the prevailing disruptive trends in the world port business, a robust first-phase port layout is required to kick-start the project and guarantee the overall sustainability of the port development. The objective of this research is to identify any uncertain or disruptive trends, both present and future, and access their implications towards the Port of Kuala Tanjung. Adaptive Port Planning (APP) framework ${ }^{a}$ will be used as the main methodology in this research. A combination of a literature review and interviews with experts are used to both identify the sources of the uncertain and disruptive trends mentioned above and also to propose adaptation strategies. Based on our qualitative study and interviews with experts, we have concluded that the consolidation of major shipping lines, multi-nationality partnerships, Indonesian regulation, and ship breaking regulations are currently the four most relevant contributions to uncertain and disruptive trends towards the port. To mitigate potential risk and seize opportunity provided by these trends, an industrial port complex concept might become the most promising alternative.
\end{abstract}

\section{Introduction}

\subsection{Background}

As a strategic national project, the Port of Kuala Tanjung in Indonesia draws significant attention at regional, national, and international level. Currently, Pelindo 1, the Port of Rotterdam, Indonesian ministries, regional government, private sector, and local communities are involved in the planning of the port. Considering the many challenges facing the project, an adaptive port masterplan is required to satisfy these challenges. These challenges include the semi-greenfield nature of the Port of Kuala Tanjung, along with the diverse set of stakeholders, international agreement in fulfilling the United Nations' goals and Paris climate agreement towards a more sustainable development, and finally the prevailing uncertain and disruptive trends in world port business aided by globalization, internet, and digitalization. This study is conducted on the Port of Rotterdam and as a part of thesis research to obtain a Master of Science in Hydraulic engineering at TU Delft. The author would like to clearly state that while this study is conducted during the author's internship at the Port of

\footnotetext{
a Taneja P, The Flexible Port, 2013
}

Rotterdam, the views expressed in this paper are those of the author alone and not the Port of Rotterdam Authority.

\subsection{Project Description}

The Port of Kuala Tanjung is an approximately 3000-hawide integrated port industrial complex development which is located approximately $140 \mathrm{~km}$ south-east of the Port of Belawan in North Sumatera, Indonesia [1]. It is strategically situated in the Malaka Strait which is the second-busiest shipping route in the world [2]. In the surrounding hinterland lies the Sei Mangkei Special Economic Zone and Medan, the second largest economic city on the island of Sumatra. A population of 13 million people living within a $250 \mathrm{~km}$ radius will be directly benefited by the presence of this industrial complex port.

Through several years, the Port of Kuala Tanjung status has gone through some changes. Beginning as a tertiary port in 2008 , it was intended to support the Port of Belawan in terms of short-sea shipping [3]. In 2015, the Indonesian government changed the status of the Port of Kuala Tanjung into an International Hub Port and placed as a national strategic project [4]. There are plans to make it the largest port in Indonesia to support the Indonesian government's "World Maritime Axis" agenda. It also serves as one of the backbones of "Tol Laut", an

\footnotetext{
*Corresponding author: author@e-mail.org
} 
Indonesian national, primary shipping line route [5]. Therefore, the port received significant attention from both a national and international audience ever since. In November 2016, the Port of Rotterdam Authority signed a JV agreement with Pelindo 1 and committed to develop a world-class port industrial complex in Kuala Tanjung.

Nevertheless, the importance of the Port of Kuala Tanjung's existence towards Indonesian connectivity and the North Sumatra region's development cannot be represented simply by its status in a national document [1]. A world-class port industrial complex located in North Sumatra will surely introduce positive influence towards the region's economy and its people's livelihood if developed and managed in efficient and sustainable way. However, like every massive infrastructure complex development, the Port of Kuala Tanjung needs to be built in phases. Prior to the JV agreement between Pelindo 1 and the Port of Rotterdam Authority, there is already a multi-purpose terminal construction which might be regarded as the first phase of the Port of Kuala Tanjung in most literature.

However, in this study we will not refer the multipurpose terminal (MPT) as the first phase of the Port of Kuala Tanjung's development. By first phase, we mean the first set of infrastructure which will be built by Pelindo 1 and the Port of Rotterdam JV. Since the main idea of the Port developed by the JV is an integrated port industrial complex, and the MPT simply do not compatible to work with the other port tenants. The focus of the Port of Kuala Tanjung JV project organization in this period would be to develop a robust, self-sustainable, first-phase development which would provide catalyzing effect towards the next phases of development.

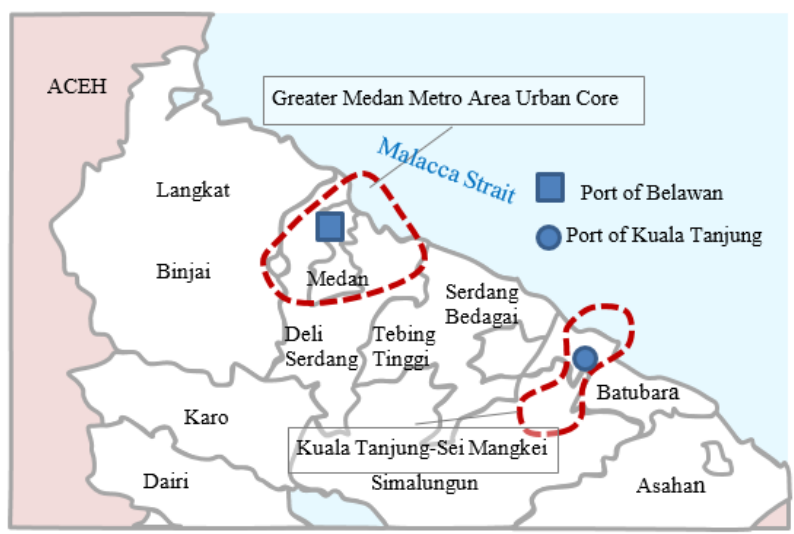

Fig. 1. Port of Kuala Tanjung site map.

\subsection{Objective of the study}

A study is being carried out in order to develop a robust, first-phase layout for the Port of Kuala Tanjung, which is self-sustainable and provides catalyzing effect towards the next stages of port development by taking into account port disruptive trends during the planning process. The result of this study will provide additional insight for decision makers and other interested parties in how to optimize the potential of the Port of Kuala Tanjung and avoid less outcome than intended.
Robustness implies that the layout and design of the port is such that the port is able to function in most plausible future scenarios. Self-sustainable indicates the ability of the Port of Kuala Tanjung's first-phase layout to gain more revenue than operating expenditure without any dependence on the next stage of development while adding significant added value to the neighboring region. A catalyzing effect applies to both a commercial context and a context based on infrastructure. In a context based on infrastructure, it implies that the first-phase port infrastructure either creates the environment of the next phase's infrastructure or avoids obstructing future construction developments, thereby enabling faster and cheaper construction work and enables clusters to develop at the next phase. In a commercial context, a catalyzing effect means that the first phase of the Port of Kuala Tanjung will consistently generate a good financial portfolio to attract potential investors and future tenants in the industrial port complex. APP framework will be used as the main framework in this research [6]. This paper presents the first results of the study, namely the analysis of the current and future uncertain or disruptive trends and their implications towards the Port of Kuala Tanjung. This is Step II in the Adaptive Port Planning Framework [6]. The completed study will include an adaptive port masterplan, robust first-phase layout, and a business case.

\subsection{Research methodology}

Port developments cover broad multi-disciplinary subjects in real practice. In order to systematically identify the implication of each ongoing trend towards the future of the Port of Kuala Tanjung development, we used port research themes to pinpoint in which topic of port development might a trend affect the Port of Kuala Tanjung. These port research themes are a result of extensive literature reviews conducted by Taneja, in which it represents every possible aspect of a port system that could be scientifically observed [6].

First, we conduct a literature review to gain a list of relevant ongoing trends which are relevant towards the Port of Kuala Tanjung project. These trends should possess both a significant disruptive effect and level of uncertainty embedded in its nature, although its actual level cannot be measured and decided through the author's qualitative judgement. We will then conduct interviews with five experts at the Port of Rotterdam who have backgrounds in port development (technical), finance, stakeholder management, economics, and commercial points of view. The focus of these interviews was to acquire expert insights in ranking the most relevant trends towards the Port of Kuala Tanjung, while identifying which port research would be affected by each trend and predict the implication of those trends towards the port's design process. 


\subsubsection{Underlying principle}

We believe that sustainable port developments should always introduce significant added value for the surrounding community while still being profitable financially and respecting nature and environment at the same time. In order to realize that, efforts in optimizing environmental and social benefit should be the main goal right from the beginning of the planning process and not just as auxiliary item for corporate social responsibility. We refer to the United Nations Sustainable Development Goals (UN-SDG) in this regard as our guiding principles [7]. It should be noted that due to its large construction and activity scale, all 17 aspects of the UN-SDG will be relevant to the Port of Kuala Tanjung's development, with number 8 (decent work and economic growth), 9 (industry, innovation and infrastructure) and 11 (sustainable cities and communities) being the top three most relevant goals in the development of the Port of Kuala Tanjung.

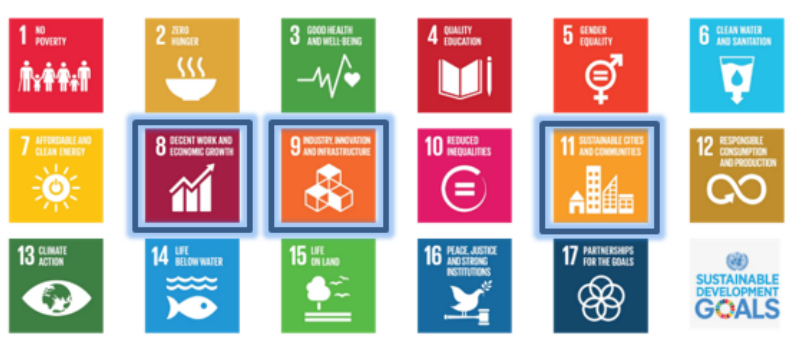

Fig. 2. United Nations Sustainable Development Goals [8].

\section{Uncertainty analysis}

\subsection{Properties of uncertainty}

Uncertainty is defined as the existence of unknown information regarding the cause and effect of a particular or series of events towards a system of interest's performance that originated either from exogenous or endogenous sectors of the system itself. In this case, the port environment will be treated as a system, or an engineering system to be exact. An engineering system is defined as a man-made system designed to meet specific objectives and functional needs that fulfill predetermined requirements [9]. The port environment is defined as a combination of technological, political, social and economic factors directly affecting the port itself [6]. It should be noted that our intention is to minimize and manage uncertainty rather than eliminating it, which is impossible. The topology of uncertainty itself is best described by Walker who categorizes it into location, level, and nature, all of which is summarized in Error! Reference source not found. below [10]. An important concept in the nature of uncertainty which needs to be further elaborated is epistemic uncertainty and inherent uncertainty. Epistemic uncertainty originates from the lack of knowledge of a system, which may be reduced through scientific research, optimization, or knowledge exchange. On the other hand, inherent uncertainty originates from the random nature of a variable itself. For example, in a steel mill, the probability that a produced steel will be up to standard may be increased through decreasing the factory's epistemic uncertainty. This means it may be achieved through better technology, production processes, or other forms of optimization. However, due to the inherent uncertainty contained in the production process, the probability that a produced steel will be up to standard will never be $100 \%$. This inherent uncertainty may be located in the variability of the iron ore's quality as the main steel mill's feedstock or in the performance variability of the steel production equipment itself.

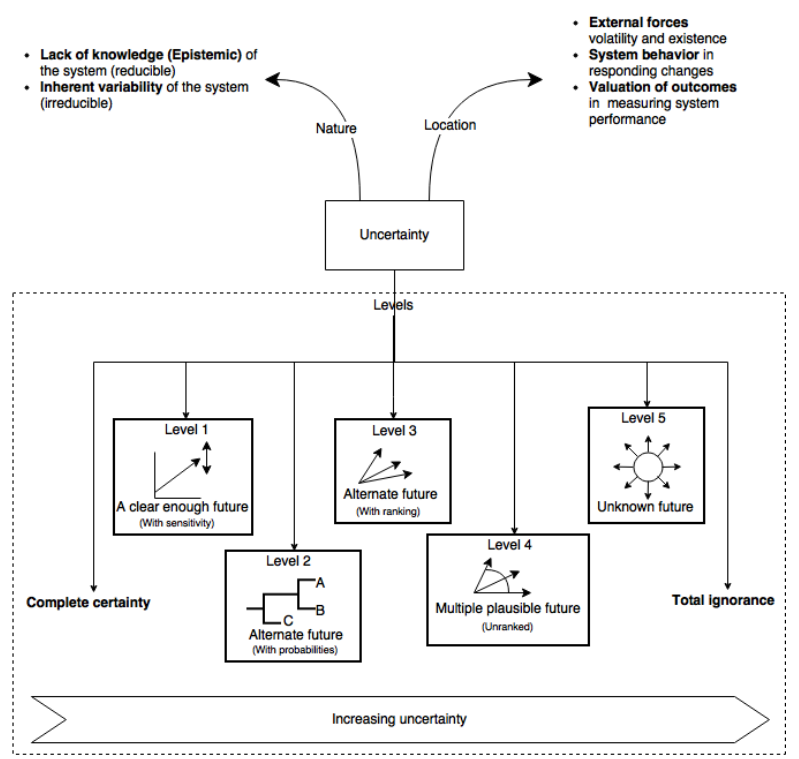

Fig. 3. Topology of uncertainty, adopted from [10].

\subsection{Properties of disruptive trends}

Daneels wrote: "Disruptive technology can be thought of as a technology that changes the essence of competition among firms by transforming the performance metrics" [11]. Based on this explanation and the uncertainty topology of Walker, we would like to propose a more elaborate definition of disruptive trends. Disruptive trends are defined as trends which add volatility into a relatively stable, long-term trend, while changing entirely how the performance of a specific topic in the system of interest is measured and eventually causing long-term trend reversal after a certain period of time. The emphasis on our definition is that disruptive trends should be timebounded. Each disruptive trend should be identified and assessed sequentially by taking into account the contribution of the previous trends and knowing that each of the trends are unique for their specific era and field of interest. However, the argument on the period, or the start and finish, of each trend depends heavily on the observer's point of view and the field of interest. Therefore, in categorizing disruptive trends it is not advisable to use time as a reference frame. The study of the effect of previous, ongoing, and potential disruptive trends on a system's performance have been conducted 
on various fields, primarily with intention to maintain the competitive edge of a company ahead of its competitors. This edge involves having the knowledge to assign appropriate resources in a way that increases the chance of benefitting or mitigating the potential vulnerabilities from the existence of disruptive trends [12].

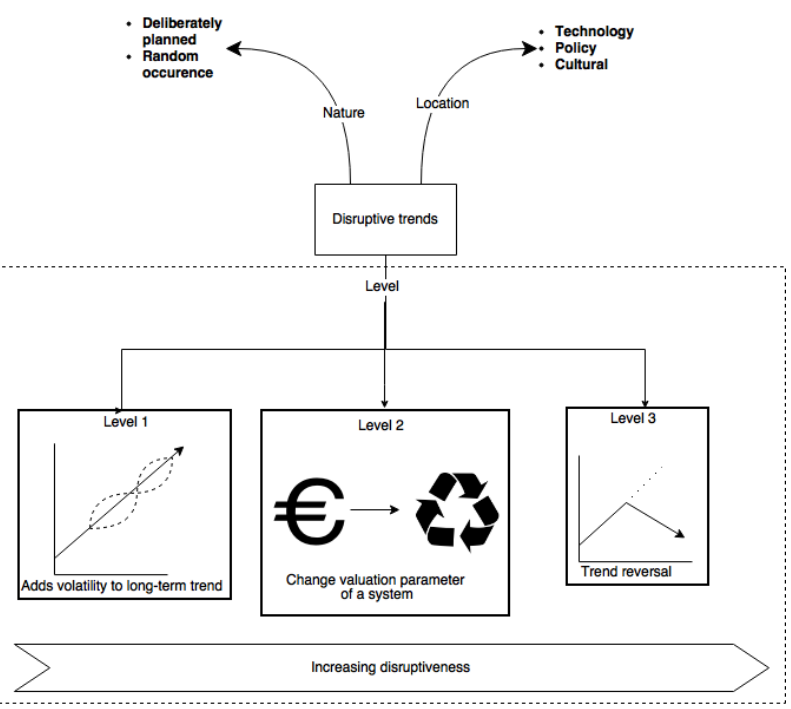

Fig. 4. Topology of disruptiveness

\subsubsection{Handling uncertainties and disruptive trends}

Uncertainties and disruptive trends can jointly be perceived as a blessing or curse in disguise depending on one's system point of view. The nature of their interaction can be visualized as in Fig. 4 with some degree of independency between each other but still somehow related. Each trend started as being "uncertainty dominated" and grew overtime towards being "disruptive-trend dominated". The uncertainty mentioned in this section only applies to epistemic uncertainty which arises from technical and scientific uncertainty, which is therefore may be reduced.

When a trend starts to occur, there is still very little data available regarding its effect towards the imposed system. Therefore, there is a huge amount of uncertainty towards this trend's performance and its profile as a disruptive trend has also not been proved. As time during the development progresses, the way both properties interact is assumed to be independent with a tendency of lowering epistemic uncertainty and growing more disruptive with time. This assumption is based on additional data and knowledge gathered overtime showing the uncertain element of the system can be reduced and the true extent of the disruptive trend effect can be discovered.

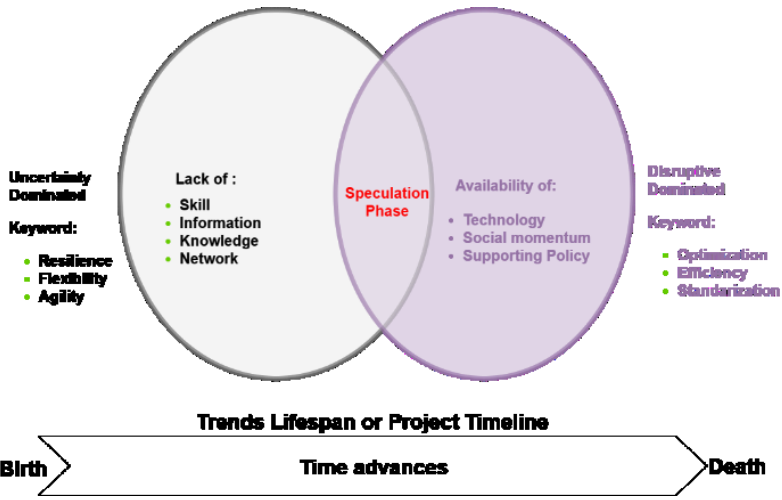

Fig. 3. Relationship between uncertainty and disruptive properties of a trend

We argue that the relationship between uncertainty and disruptive trends in Fig. 5 is also applicable for port projects. In the green-field stage, ports are dominated by uncertainty in their development. There are simply too many elements in the port construction, management, and commercial services that are still not known, even with a state-of-the-art forecasting method. The challenge for this stage of development is that ports need to invest in a significant amount upfront for large infrastructure without having a guaranteed revenue stream in the process. This condition places greenfield ports in huge financial risk. Therefore, the focus of these ports should be on resilience, flexibility, and agility.

While for a matured, brownfield port, epistemic uncertainties should be near diminished due to prolonged exposure towards the port operation as well as experienced workers and a well-established port organization. These ports are dominated by ongoing disruptive trends. The scale of the disruptive trends differ depending on the scale of the ports. For instance, gateway ports are affected by global disruptive trends while small, feeder ports are only affected by regional disruptive trends. In order to prevent stagnantization and maintain its competitive edge compared to other port competitors sharing the same hinterland, brownfield ports should focus on optimization, efficiency, and standardization.

Having illustrated the complexity surrounding uncertainty and disruptive trends in port industry, proper identification and relevant strategies are required to manage it optimally. Nonetheless, only those who are cautious, agile, knowledgeable, and visionary enough can gain real benefit and grow from it. Uncertainties and disruptive trends are part of the eternal cycle of the world and will stay forever. Ports will be forced to either take advantage and prosper from it or suffer defeat and lose from it. 


\subsection{Major trends relevant to The Port of Kuala Tanjung}

\subsubsection{Consolidation of shipping lines}

Fair competition has always been the nature of shipping line industries. In order to attract customers, large number of shipping lines constantly compete with each other by reducing costs while maintaining their safety level to ensure their cargo arrives at destinations. As a result of this competition, a trend of larger ships has started to occur in maritime industries to further lower the cost of logistics. Larger ships mean more,cargos to transport in one trip which leads to better efficiency. However, as the trend progresses, the world shipping line industry will eventually reach overcapacity meaning there are more ships available than the cargo which has to be transported. To solve the problem of overcapacity, shipping companies started making alliances in order to optimize the utilization of large ships in their fleet [13]. This action proved to be a good one as it benefits all shipping line companies within the alliances. Currently, there are four major alliances recognised in the world as presented in Table 1. The trend of alliances is expected to continue in dynamic fashion as the power balance between each shipping line company always fluctuates. This trend will then lead towards a consolidation of shipping lines in the world, resulting in fewer calls with same or even more throughput for all the ports in the world.

Table 1. Current shipping alliances in operation [14]

\begin{tabular}{|c|c|c|c|c|}
\hline Alliance & Members & Est. & $\begin{array}{l}\text { Market } \\
\text { Share in } \\
\text { the } \\
\text { World }\end{array}$ & $\begin{array}{l}\text { Fleet } \\
\text { Size }\end{array}$ \\
\hline CKYHE & $\begin{array}{l}\text { COSCO, K- } \\
\text { line, } \\
\text { Yangmig, } \\
\text { Hanjin, } \\
\text { Evergreen }\end{array}$ & 2002 & $25 \%$ & $\begin{array}{l}3.3 \mathrm{M} \\
\text { TEUs }\end{array}$ \\
\hline $\begin{array}{l}\text { G6 } \\
\text { Alliance }\end{array}$ & $\begin{array}{l}\text { APL, Hapag- } \\
\text { Lyod, HMM, } \\
\text { MOL, NYK } \\
\text { Lines, OOCL }\end{array}$ & 2012 & $28 \%$ & $\begin{array}{l}3.5 \mathrm{M} \\
\text { TEUs }\end{array}$ \\
\hline $\begin{array}{l}2 \mathrm{M} \\
\text { Alliance }\end{array}$ & Maersk, MSC & 2015 & $27 \%$ & $\begin{array}{l}5.7 \mathrm{M} \\
\text { TEUs }\end{array}$ \\
\hline $\begin{array}{l}\text { Ocean } \\
\text { Three } \\
\text { Alliance }\end{array}$ & $\begin{array}{l}\text { CMA-CGM, } \\
\text { China } \\
\text { Shipping, } \\
\text { United arab } \\
\text { shipping co }\end{array}$ & 2015 & $15 \%$ & $\begin{array}{l}3.0 \mathrm{M} \\
\text { TEUs }\end{array}$ \\
\hline
\end{tabular}

Since major shipping line companies are highly competitive, they only call to terminals which offer the best service in terms of time and cost. Relying on a transshipment business model introduces significant risk to the Port of Kuala Tanjung considering there are already exists the well-established Port Klang and the Port of Singapore which are both placed as the top 15 container ports in the world. Confronting direct competition with these ports through transshipment activity would not be a wise move, since they could simply reduce their price or increase their productivity which then would hurt the Port of Kuala Tanjung financially. Moreover, transshipment ports introduce minimum added value towards the neighboring region since the cargo flow which is generated directly by these activities would not be retrieved by the hinterland. This is often referred to as "lose feet" cargo.

\subsubsection{Multi-national company partnerships}

There is a considerable difference between the Port of Rotterdam and the Pelindo 1 Port's governance model. Before 2008, Indonesia adopted the service port model, where the role of Terminal Operator and Port Authority was both conducted by four state-owned companies called Perusahaan Pelabuhan Indonesia (Pelindo). According to state regulation, No. 21, Year 1992 about shipping, these four pelindos were given the authority to regulate ports in all cities within their territory as illustrated in Fig.6.

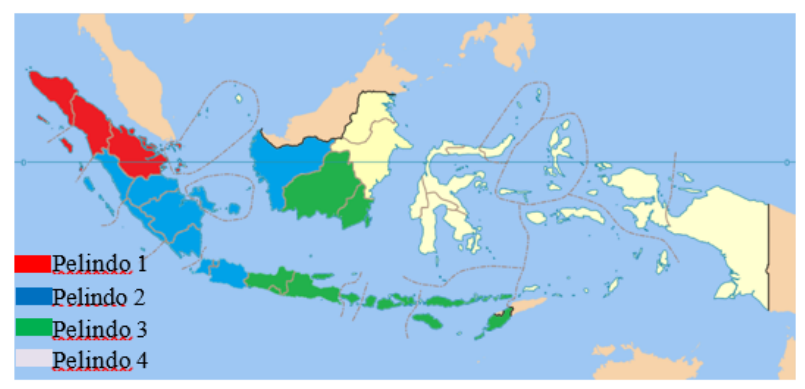

Fig. 4. Pelindos designated territories

In a newly amended shipping regulation in 2008 (state regulation No. 17), the government made significant changes to the shipping laws. Pelindo, which previously held total control of the planning, construction, regulation, and operation of all ports in the region, now only acts as the port operator as a result of the amendment. The Port Authority role will be given to a new government institution, Otoritas Pelabuhan, which acts under the Ministry of Transportation. This indicates the Indonesian Government's intention to change the service port governance model into a land-lord port governance model. It should be noted here that Pelindo does not only act as the terminal operator in their capacity as the port operator. They also have the power to control a range of operations within the port, ranging from berthing navigation, cargo handling, and hinterland activities. Therefore, their role extends beyond a terminal operator. The new entity, Otoritas Pelabuhan will assume the role of port master planner and will act as a regulating body for all port related activity. For instance, if Pelindo wishes to expand their terminal, they would need to first obtain approval from Otoritas Pelabuhan.

However, due to unclear separation of duties between Pelindo and Otoritas Pelabuhan and the absence of a clear, time-bound transition plan in 2008 regulation No. 17, changes to the Indonesia port governance model have been minimal since then. Typically, in a landlord 
port model, the Port Authority represents a form of publicly owned enterprise. One such example would be the Port of Rotterdam which owns the land under the municipality jurisdiction. They have the authority to regulate the lands given to them by the government provided that they abide by certain city rules and regulations. They obtain their main revenue stream from a land-lease fee and port dues. They do not handle daily port operations directly as this task is handled by terminal operators which rent the land from the Port of Rotterdam. In Indonesia however, the majority of land ownership still belongs to Pelindo and not to the newly established Otoritas Pelabuhan. There are even some pieces of land inside port areas that belong to private companies or individuals. Otoritas Pelabuhan is only acting as a government regulatory agency without any commercial activity in the institution's agenda. A summary of the difference in responsibility allocation between the Port of Rotterdam and Pelindo 1 is presented in Table 2.

Table 2. Responsibility allocation in Port of Rotterdam and Pelindo 1.

\begin{tabular}{|l|l|l|l|}
\hline Responsibility & $\begin{array}{l}\text { Port of } \\
\text { Rotterdam }\end{array}$ & $\begin{array}{l}\text { Pelindo } \\
1\end{array}$ & $\begin{array}{l}\text { Otoritas } \\
\text { Pelabuhan }\end{array}$ \\
\hline Commercial & & & \\
\hline Planning & & & \\
\hline Infrastructure & & & \\
\hline $\begin{array}{l}\text { Nautical safety } \\
\text { \& security }\end{array}$ & & & \\
\hline Regulation & & & \\
\hline $\begin{array}{l}\text { Stakeholder } \\
\text { management }\end{array}$ & & & \\
\hline $\begin{array}{l}\text { Marine service } \\
\text { \& utilities }\end{array}$ & & & \\
\hline Supra-structure & & & \\
\hline Logistics & & & \\
\hline
\end{tabular}

Another source of uncertainty and disruptive trends related to the $\mathrm{JV}$ culture is the differences between Indonesia and The Netherlands with regards to communication style and the way in which projects are approached. Based on his working experience, Lewis has conducted a study on how cultural background might affect someone's communication and behavior [15]. He then measured each country in terms of three general criteria and plotted them into Fig.7. This is commonly referred to as the "Lewis model".

Indonesia and The Netherlands are assigned to opposite sides of the figure in the Lewis model, indicating significant difference in communication style and behavior influenced by each country's respective cultural-background differences. Indonesia is said to be culturally reactive, while The Netherlands is assumed to be linear-active. Countries with reactive cultural values place courtesy and politeness in high regard. They prefer to look at the general picture, conceal their feelings, and most notable, they prefer to listen. On the other side of the spectrum, The Netherlands tends to prefer a more direct approach. They plan ahead, step-by-step in detail, and culturally have no difficulty in expressing their feelings.
The approach on problem-solving and the way Indonesians and Dutchs people treat their business partner is indeed very much different. These differences might become the source of conflict which put the partnership at stake or become the source of strength that gives the Port of Rotterdam and Pelindo $1 \mathrm{JV}$ a unique advantage against their competitors through collective knowledge and diverse yet comprehensive approach on port related problems. We believe that there is even more potential than risks that could be realized through this partnership. Dedicated studies and discussions in deciding how Pelindo 1 and Port of Rotterdam should cooperate with each other is required in order to truly complement each other's strengths, and making Pelindo 1 and Port of Rotterdam the best port managers in their respective region.

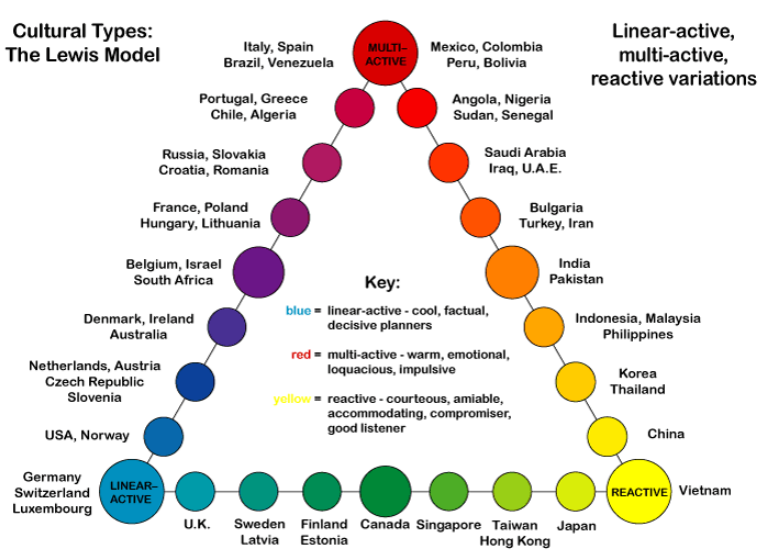

Figure 5: Lewis Model [15].

\subsubsection{Ship breaking regulations}

Even after eight years since Hong kong convention on ship breaking in 2009, most of ship breaking activity still take place in substandard ship breaking yard facilities located in Bangladesh, Pakistan, and India which violates international safety and environmental standard [16]. There could be several reason for this trend, one of them arguably is the lack of law environment for ship owners and ship breaking yards which violates the international regulations [17]. Ship owners could simply choose the cheapest, non regulated ship breaking yard available in the world without having any real consequence in doing so. Numerous worker causalities and massive environmental damage in the coast happened where non regulated ship breaking activities take place.

However, recently global pressure towards a more green ship breaking facility have increased. European commission have published a list of registered ship recycling facilities on December 2016, as a shown commitment from the EU in attempt towards a more green ship breaking industry [18]. If we take into account the raised global awareness aided by internet, global common goal provided by UN-SDGs, we believe that sooner or later ship breaking industries will transformed into a more sustainable industry. If we could eliminate the negative effect of ship breaking activity by having the state of the art ship breaking facilities, a potentially huge 
benefit could be introduced into the region through: steel production, massive low education-employment, generated economic activity and the compatibility of a ship breaking facility to integrate with industrial cluster.

Table 3. Total dismantled ships worldwide vs ships dismantled in substandard ship breaking facilities [16].

\begin{tabular}{|c|c|c|}
\hline Year & $\begin{array}{c}\text { Total } \\
\text { dismantled } \\
\text { ships } \\
\text { worldwide }\end{array}$ & $\begin{array}{c}\text { Ships dismantled in } \\
\text { substandard beaching } \\
\text { facilities in India, } \\
\text { Pakistan, and Bangladesh }\end{array}$ \\
\hline 2012 & $\sim 1213$ & $850(70 \%)$ \\
\hline 2013 & 1213 & $645(53 \%)$ \\
\hline 2014 & 1026 & $641(62 \%)$ \\
\hline 2015 & 768 & $469(61 \%)$ \\
\hline 2016 & 862 & $668(77 \%)$ \\
\hline
\end{tabular}

\subsubsection{Regulation and legal permits in Indonesia}

Based on interviews with experts at the Port of Rotterdam, it was concluded that the legal frame work is not yet ready in Indonesia in order to apply a landlord port model. In order for a landlord port model to work optimally, a single entity which takes the role of the port manager is required. This usually takes the form of a port authority which regulates, manages, and plans all related port activities and developments. By giving full authority to the port manager, full integration of port shared facilities and sustainable development can be achieved. In contrast, Indonesian ports see various industrial activities under the authority of many different entities. Ports are, in essence, an established set of required logistics infrastructure which allow cargo movement between sea and land. They are not considered to be industrial complexes. Hence, in Indonesia, the ports lay under the authority of the Ministry of Transportation, while industrial complexes fall under the authority of the Ministry of Industry. Moreover, the division of the regulatory and management role of the port manager between Otoritas Pelabuhan (regulatory) and Pelindo 1 (managerial) make the application of a landlord port model difficult. Therefore, customized regulatory efforts are required in order to simplify but not undermine the regulatory framework related to the construction of the Port of Kuala Tanjung.

\subsection{Implications for The Port of Kuala Tanjung}

Considering the various challenges posed by ongoing and forecasted future disruptions, the Port of Kuala Tanjung needs to develop adaptive plans to truly become a worldclass port as envisioned by the Indonesian government. Relying on a static and rigid port masterplan would not be advised as the nature of these disruptive trends are uncertain. Many parameters in the masterplan which are being used for the current design criteria may change in the future. For this reason, the first crucial step in determining the future of the Port of Kuala Tanjung would be affirming what kind of port it should be in order to become a world-class port. This will support the Indonesian "World Maritime Axis" and the "Tol Laut" agenda. By comparing common characteristics between the top 15 busiest container ports in the world, we have identified key elements required to become a world-class port. There should be an optimal combination of: populous urban hinterland, significant industrial activity inside the port area, and a frequent stream of dedicated shipping line traffic. The management of each port in Table 4 has focused on at least one of the identified key elements resulting in the port maximizing its performance.

Table 4: Top 15 largest container ports in the world [19].

\begin{tabular}{|l|l|l|}
\hline Rank & Port & Terminal Operator \\
\hline 1 & Shanghai, China & APMT, Hutchison, \\
\hline 2 & Singapore & PSA and Jurong \\
\hline 3 & Shenzhen, China & CMHI and COSCO \\
\hline 4 & Ningbo -Zhousan, & Hutchison, TIL, etc. \\
\hline 5 & Hong Kong, S.A.R, & DP World, PSA, etc. \\
\hline 6 & Busan, South Korea & Hutchison \\
\hline 7 & Qingdao, China & DP World and \\
\hline 8 & Guangzhou, Harbour, & PSA and COSCO \\
\hline 9 & Jebel Ali, Dubai, & DP World \\
\hline 10 & Tianjin, China & APMT, DP World, \\
\hline 11 & Rotterdam, Netherlands & APMT, Hutchison, \\
\hline 12 & Port Klang, Malaysia & APMT \\
\hline 13 & Kaohsiung, Taiwan, & DP World \\
\hline 14 & Antwerp, Belgium & PSA, TIL, and DP \\
\hline 15 & Dalian, China & APMT, PSA, etc. \\
\hline
\end{tabular}

In the case of the Port of Kuala Tanjung, we will first describe the implications of the trends mentioned in previous sections and then draw conclusions on how to optimize the port. First, the implication of the consolidation of major shipping lines is considered. Bigger and less frequent vessel traffic would result in higher peak cargo flow in the respective port. This trend would put additional stress on not only the port infrastructure, but also its hinterland connections. Wider reaching cranes, stronger quays, and wider roads among other things are required in order to avoid possible congestion at the moment of cargo discharge from large vessels. The Port Authority and the city municipality need to cooperate fully to mitigate this risk. The focus in this regard should not be on the vessel size itself, but on the maximum cargo flow capacity that the whole port system and the cities in the surrounding hinterland area could manage at any one time. On the other hand, the birth of major shipping alliances offers a significant opportunity. Large, steady numbers of yearly cargo flow are expected as a result of these new alliances. The existence of a world-class terminal operator in this region is crucial to attracting shipping traffic from these major shipping line alliances. Even when operating individually, shipping lines tend to be attracted to the most efficient terminal in the region so that they maintain their competitive position. The consolidation of major shipping alliances would surely increase their demand for more efficient cargo handling in a terminal. The best course of action for the Port of Kuala Tanjung manager (Pelindo 1 and the Port of Rotterdam JV) in this case would be to maintain a neutral position when appointing 
the terminal operator and perform objective periodical assessment on the terminal operator's performance. By doing this, the Port of Kuala Tanjung can maintain a competitive position over Port Klang and the Port of Singapore in terms of its container terminal handling facility and efficiency.

Next, we would like to elaborate on the implications due to the Multi-nationality partnerships and Indonesian governmental regulations. Both aspects will directly affect the management and day to day operation of the Port of Kuala Tanjung. A major cause of debate resulting from the multi-nationality partnerships was authority designation for each company department or subsidiary. This was due to differences between the Pelindo 1 and the Port of Rotterdam port governance models. It should be noted that each port governance model is not a fixed rule. There are no perfect port governance models and each of them are developed according to the objectives and needs of the port in which they are applied. Therefore, in the Port of Kuala Tanjung, it is possible that a hybrid port governance model will be used, which in essence would involve a combination of a service and landlord port model. The main idea would be to adjust the landlord port governance model in such a way that it follows Indonesia's current regulatory framework. However, it should be emphasized that since the ambition of the Port of Kuala Tanjung is to become a world-class port, the port managers should stay neutral when it comes to the selecting terminal operator. The focus of the JV between the Port of Rotterdam and the Port of Kuala Tanjung should be on cooperation and harmony between both companies in order to facilitate knowledge transfer and the sharing of expertise. One solution would be to establish remote Project Organization (PO) in the Port of Kuala Tanjung with the Port of Rotterdam and Pelindo $1 \mathrm{JV}$ as its shareholder. The main idea is to separate the detailed day to day operation task and the long-term political or strategic planning responsibility. The PO would be in charge of day-to-day operations, port development, and port master planning while the JV will have the authority to conduct long-term strategic planning and negotiate political terms with relevant stakeholders outside the Port of Kuala Tanjung system. A significant benefit of this solution would be the simplification of the decision-making process in the Port of Kuala Tanjung. This increases the port's responsiveness and efficiency and allows it to compete with Port Klang and the Port of Singapore. If done correctly, the advantages of the partnership with the Port of Rotterdam can be fully realised. Its experience in developing the largest port industrial complex in Europe combined with the expertise of Pelindo 1 in conducting stakeholder management with relevant Indonesian stateowned enterprises and government bodies would surely give rise to another world-class port facility.

Finally, the implication of ship breaking regulations is considered with respect to the Port of Kuala Tanjung. This trend offers a great long-term opportunity for port of Kuala Tanjung industrial complex. It is expected that the shipping industry will continue to grow to facilitate world economic growth. It follows that the demand for ship breaking will steadily increase over the coming years. The existence of a state-of-the-art ship breaking yard which fully complies with existing international regulations (i.e. IMO \& EU) in the Malaka strait region will give the Port of Kuala Tanjung a competitive edge against its competitors, further securing Indonesia's position as the "World Maritime Axis". However, it is not our intention so simply advise the Port Authority to construct ship breaking yard in the Port of Kuala Tanjung. This would not fully achieve the desired benefits. The true strength of a port industrial complex resides in its seamless integration between port infrastructures and industrial cluster thereby enhancing its overall system efficiency and self-sustainability. By doing so, a significant amount of jobs are created when compared to a regular gateway or transshipment port. Through a combination of numerous cargo handling activities in the port and industrial activity in the industrial cluster stimulus, significant regional economic growth can be achieved. Moreover, due to its high efficiency, environmental risk could be kept to a minimum. For instance, a cluster of a ship breaking yard, steel plant, aluminium plant, coal stacking area, coalpowered electricity plant, and dry bulk terminal would provide a complete industrial cycle in the Port of Kuala Tanjung. The key objective in this case would be to find industrial activity opportunities which are profitable and promotes significant added value to the region. This must be done without compromising the profitability of planned and pre-existing industries. This concept put into practice may involve the recycled steel from the ship breaking facility being used in a nearby steel plant before finally being shipped outside the region through the Port or distributed to hinterland areas in the region. This industrial cluster model would enhance the robustness and self-sustainability of the Port of Kuala Tanjung, minimizing its dependency on cargo flow from the shipping line companies.

\section{Conclusions}

In order to establish an adaptive port plan for the Port of Kuala Tanjung, relevant industry trends and the implications of such trends have been analysed. Based on qualitative studies and interviews with industry experts, we have concluded that the consolidation of major shipping lines, JV culture, Indonesian governmental regulations, and ship breaking regulations are four critical areas of uncertainty and disruptive trends for the Port of Kuala Tanjung. It should be noted that each of these areas have inherent uncertainty which is not reducible with further research. The true extent of these uncertainties and the resulting effects are difficult to quantify.

One solution posed to mitigate the negative effects of uncertainty while taking advantage of available opportunities is the establishment of a port industrial complex. The advantage of this concept being that the port area is that it produces steady cargo traffic due to its own industrial activity as compared to gateway or 
transshipment ports which have a huge dependency on shipping lines for cargo. Moreover, this concept focuses on the integration of port facilities and activities which cultivates a more efficient and environmentally friendly port ecosystem. Another advantage of this concept would be the significant added value such a development brings to the industrial port complex and to the neighboring region in the form of jobs and stimulus for regional economic growth while presenting minimum environmental risk due to its high efficiency.

However, an industrial port complex requires a landlord port model to be implemented. Due to the existing Indonesian governmental regulatory framework, it might be a challenge to directly apply a landlord port model in exactly the same manner as in the Port of Rotterdam. The port governance model itself should be adapted to meet Indonesian regulatory framework. A hybrid port model might be a solution in this case. As the port model is implemented, it could be adapted accordingly provided there is a single port manager entity which maintains a neutral position in the regulation, management, and planning of the Port of Kuala Tanjung area.

\section{Acknowledgements}

The authors would like to express our gratitude toward the Indonesian Ministry of Finance for funding this study through the LPDP program. Also acknowledged is an appreciation of the Port of Rotterdam International Department for their huge support in providing the required data and in coordinating interviews with industry experts.

\section{References}

[1] Santoso, P., Direktur Pemberitaan Media Indonesia Berkunjung ke Pelindo 1, Majalah Gema Pelabuhan, April 2016 (4),

http://www.pelindo1.co.id/wps/wcm/connect/316a3513-f6774dc8-a3236687f0d00496/Gema+April+2016.pdf?MOD=AJPERES, 2016

[2] Hirst, T., The world's most important trade route?, World Economic Forum, https://www.weforum.org/agenda/2014/05/world-mostimportant-trade-route/, 2014

[3] Pemerintah Provinsi Sumatera Utara, Rencana Pembangunan Jangka Panjang Daerah (RPJPD) Provinsi Sumatera Utara, Tahun 2005 - 2025, Peraturan

Daerah Provinsi Sumatera Utara, 2008

[4] Presiden Republik Indonesia, Percepatan pelaksanaan proyek strategis nasional, PP 3 th 2016, 2016

[5] Direktorat Transportasi., Laporan Implementasi Konsep Tol Laut 2015, Bappenas Indonesia,

http://nusantarainitiative.com/wpcontent/uploads/2016/02/150915-Buku-Tol-Laut-bappenas.pdf, 2015

[6] Taneja, P., The flexible port. Proefschrift. With assistance of H. Ligteringen, W. E. Walker. Delft: Next Generation Infrastructures Foundation (NGInfra PhD thesis series on infrastructures, 59), 2013
[7] Osborn, D., Ullah, F., Universal Sustainable Development Goals, Understanding the Transformational Challenge for Developed Countries, Stakeholder Forum, https://sustainabledevelopment.un.org/content/documents/1684 SF__SDG_Universality_Report___May_2015.pdf, 2015

[8] United Nations Department of Public Information, Sustainable Development Goals. Guidelines for the use of the SDG Logo, Including the colour wheel, and 17 icons, United Nations Department of Public Information, 2016

[9] Blanchard, B., Fabrycky, W.J., System engineering and analysis. NJ, USA: Prentice Hall, 2011

[10] Walker, W., Harremos, P., Rotmans, J., van der Sluijs, J., van Asselt, M., Jannssen, P., and von Krauss, M., Defining uncertainty: A conceptual basis for uncertainty management in model-based decision support. Integrated Assessment, 4(1):517, 2003

[11] Danneels, E., Disruptive Technology Reconsidered, A Critique and Research Agenda. Journal of Product Innovation Management 21 (4), pp. 246-258. DOI: 10.1111/j.07376782.2004.00076.x, 2004

[12] Dotsika, F., Watkins, A. Identifying potentially disruptive trends by means of keyword network analysis. Technological Forecasting and Social Change. DOI: 10.1016/j.techfore.2017.03.020, 2017

[13] Wright, R., Container shipping lines mired in crisis. Financial times. New york. Available online at https://www.ft.com/content/1e98963c-1853-11e6-bb7dee563a5a1cc1?mhq5j=e1, 2016

[14] OECD, Competition issues in liner shipping. Working Party No. 2 on Competition and Regulation. Edited by Ana Rodrigues. OECD. Genova, 2015

[15] Lewis, R.D., When Cultures Collide. Leading Across Cultures. Boston: Nicholas Brealey International, 2006

[16] NGO Shipbreaking Platform, Global Dumpers List. 4 volumes: NGO Shipbreaking Platform,

http://www.shipbreakingplatform.org/annual-lists-of-scrappedships/, 2013-2016

[17] mrlee, Off the Beach, NGO Shipbreaking Platform, http://www.offthebeach.org/, 2013

[18] European Commission, European list of ship recycling facilities,

http://ec.europa.eu/environment/waste/ships/pdf/list ship recy cling facilities.pdf, 2016

[19] World Shipping Council, Top 50 World Container Ports, http://www.worldshipping.org/about-the-industry/globaltrade/top-50-world-container-ports, 2015 